\title{
The Influence of Transformational Leadership Organizational Culture on Employee Performance with Job Satisfaction as Mediating Variable in Ibnu Sina Hospital in West Sumatera
}

\author{
Welly Nuansa Adri ${ }^{1}$, Susi Evanita ${ }^{2}$, Dina Patrissia ${ }^{3 *}$ \\ ${ }^{1}$ Universitas Negeri Padang,indonesia, $\square$ nuansaadri@gmail.com \\ ${ }^{2}$ Universitas Negeri Padang,indonesia, $\square$ susievanita@gmail.com \\ ${ }^{3}$ Universitas Negeri Padang,indonesia, $\square$ patrisiadina@yahoo.com \\ ${ }^{*}$ Corresponding Author
}

\begin{abstract}
This study has several objectives, first analysing and proving the influence of transformational leadership style on employee performance. Second, analyse and prove the influence of organizational culture on employee performance. Third, analyse and prove whether there is an influence of transformational leadership on employee performance through job satisfaction as a mediating variable. Fourth, analyse and prove the influence of leadership style on job satisfaction. Fifth, analyse and prove the influence of organizational culture on employee performance through job satisfaction as a mediating variable. Sixth, analyse and prove whether there is an influence of job satisfaction on employee performance. In this study the population is all permanent employees at Ibnu Sina Hospital in West Sumatera. while the sample was 262 respondents who were searched using Sugiono's formula. The types and sources of data used are primary data by distributing questionnaires. For analysis testing using validity and reliability tests and using path analysis, as well as processing data using the latest SPSS model. In accordance with the hypothesis testing it was found that transformational leadership had a significant effect on job satisfaction. In organizational culture has a significant effect on job satisfaction. Third, transformational leadership has a significant effect on performance. found organizational communication has a significant effect on performance. Fourth, the organizational culture has a significant effect on performance. While job satisfaction has a significant effect on performance. Sixth, the effect of transformational leadership on employee performance through job satisfaction as an intervening variable in Ibnu Sina Hospital in West Sumatera has a direct relationship. The seventh influence of organizational culture on employee performance through job satisfaction as a mediation variable at Ibnu Sina Hospital in West Sumatera has a direct relationship.

Keywords: Transformational Leadership, Organizational Culture, Job Satisfaction, and Performance.
\end{abstract}

\section{Introduction}

The reliance of Ibnu Sina Islamic Hospital West Sumatera on human resources is huge, for that it is necessary that human resources with high motivation, high motivation in working, strong in the face of challenges and obstacles, have the initiative and inspiration and the right strategy in managing employees. Ibnu Sina Islamic Hospital In West Sumatra requires human resources that have attachments to their work, in terms of human resources Ibnu Sina Islamic Hospital in West Sumatera with excellent quality by having a good level of education, the amount of human resources available in Ibnu Sina Islamic Hospital in West Sumatera has an education level, ranging from nurses, general practitioners, and employees. The high level of work ability of employees will bring changes in employee attitudes in improving the attachment, both to work and organization. Of course, in managing such capabilities, the role of a leader is crucial in aligning organizational goals with employee satisfaction to their work. 
Leadership style is an important factor in managing the ability of employees to complete their work, transformational leadership is a leadership action involving change great influence on the attitudes of members or employees and building commitments for Robbins and Coutler's company mission, goals, and strategy (2008: 455). Being a transformational leader must be able to convey a clear and compelling vision, always confident and optimistic, celebrate success together, lead with real applications and always empower human resources to achieve that vision. In addition to managing the ability and directing employees in their work a leader must be able to harmonize with the culture in the organization, because culture is the norm of norms that must be well-connected. Organizational culture has a central role to play in the organization, what employees are doing should be in keeping with the culture of the organization itself. Culture is a philosophy and value that has been agreed upon and assumed by all human beings as a foundation and a reference to the organization in working to achieve its goals. An early observation of the author in Ibnu Sina Islamic Hospital In West Sumatra, seeing the symptoms and data of direct data from the hospital was seen that the worker had not shown a good result, this was because many employees were still often late in work hours, often postpone the work and it is rare for employees to complete additional duties given by the leadership and even the reprimand and sanctioned by the leaders are rarely performed well.

The leadership factor in the hospital has a huge impact on the performance and decline of employee work. Will be a special concern Ibnu Sina Islamic Hospital is an indicator of the attitudes of employees to their superiors, it appears that no assessment results show that the outcome is good, it should be the special attention of the leaders to their duties and responsibilities on emotionally enlightened employees should be better. This will certainly be detrimental to companies in the present and future periods and will be very difficult to produce employees who have the responsibility and quality of their work and achieve organizational goals. The often decreasing indicator is seen in relation to employee boss and behavior, for that it is necessary good management in managing the skills and expertise of employees in their work and building and establishing good relationships with employees. Conducting an internal approach to employees is certainly not easy to require specialized expertise in handling employees so that employees can be motivated and aware of their responsibilities in their work. One is the transformational leadership style where the transformational leadership style is a leadership action that involves major changes in the attitudes of members or employees and building a commitment to the company's mission, goals, and strategies.

Almost every human has the potential to act in various forms of activity. The ability to act can be acquired naturally (either from birth) or studied. Although humans have the potential to behave but the behavior is only validated at certain moments. The potential for such a behavior is called ability, while the expression of this potential is known as Performance Hasibuan (2003: 6) argues that performance is a result of the work achieved by a person in executing tasks charged to him who are based on proficiency, experience and sincerity and time. In other words, performance is the result of work accomplished by someone in performing the tasks assigned to them in accordance with the criteria set. There are 3 (three) major factors affecting performance ie individual (working ability), work (desire to work), and organizational support (opportunity to work). According to Hughes (2012: 331), behavior-related performance towards the goals or mission of the organization, or products and services resulting from such behavior. According to Dessler (2015: 95). Employee performance is the contribution of each employee to achieving strategic goals. The company as a whole, helps managers and understand the tasks that are carried out in achieving organizational goals seen from employee efforts with the achievement of organizational goals and Wirawan (2015: 238), performance is a recording of outputs of the performance or demands of the work within a certain time. Furthermore, As'ad in Agustina (2002) and Sutiadi (2003: 6) argues that one's performance is a measure of the extent to which one's success in performing his job duties. There are 3 (three) main factors that influence performance namely work ability, work, and organizational support. compensation plans, communication systems, managerial styles, organizational structures, policies and procedures. Performance is the achievement of organizational goals that can be in the form of quantitative or qualitative outputs, creativity, flexibility, dependability, or other things that the organization wants. 
Performance emphasis can be short- and long-term, as well as at individual, group or organization level. Performance management is a process designed to link organizational goals to individual goals, so both ends meet. Performance may also be an action or execution of tasks that have been completed by a person within a certain period of time and can be measured. According to Rivai (2009: 548) performance is a function of motivation and ability. To accomplish a task or work someone should have a degree of willingness and a certain level of ability. One's willingness and skill is not effective enough to do something without a clear understanding of what to do and how to do it. Performance is a realistic behavior that every person displays as a work achievement produced by employees in line with their role in the company. Employee performance is a very important thing in the company's efforts to achieve its goals. In accordance with the brief description some of the theoretical expressions of some of the experts have been concluded that performance is the result of the function of a person or group's work / activity within an organization influenced by various factors to achieve organizational goals within a certain period of time.

Employee performance is influenced by many factors, individual and contextual factors. The individual factor is based on an employee, ie, the competence, the discipline, the responsibility, the motivation, and the goal. While contextual factors such as leadership style, organizational culture and organizational communication (Mangkunegara 2005: 120 - 121).Other internal organizational factors such as organizational strategies, organizational cultures are needed to carry out work, as well as management systems, and compensation. Therefore organizational management must create a conducive internal organizational environment that can support and improve employee productivity.

According to Hasibuan (2012: 202), job satisfaction is an emotional attitude that works fun and loves work. Furthermore, Mangkunegara (2009: 117), stated that job satisfaction is a feeling that does not have a tendency to stifle the work-related employees or their working conditions. Dole and Schroeder (2001) in Koesmono (2005), argue that job satisfaction can be defined as individual feelings and reactions to the work environment. Testa (1999) and Locke (1983) in Koesmono (2005) argue that job satisfaction is a joy or positive emotional statement as a result of the assessment of one's work or work experience.

Transformational leadership focuses on the concept of positive attribution in achieving performance beyond expectations. Transformational leaders achieve their goals through increased awareness of the importance of value creation in making a plan of achievement of results and realizing it, establishing good relationships across team members, organizations and all stakeholders and can distinguish between the needs and desires that need to be met (Tauber 2012).According to Robbins and Coutler (2008: 455) the transformational leadership style is a leadership action that involves major changes in the attitudes of members or employees and building commitments for the company's mission, goals, and strategies. To be a transformational leader, the leader must be able to convey a clear and compelling vision, always confident and optimistic, celebrate success together, lead with real applications and always empower human resources to achieve that vision. In transformational leadership, the leader inspires his followers and has a huge foothold for the company and the environment around the company. In transformational leadership, leaders inspire their followers and have a great impact on the company and the environment around the company.

1. The four components according to Bass and Avolio (2011; 159), are as follows: Idealized Influence, which is described as a behavior that results in the respect and confidence of the people he leads. This Idealized Influence contains the meanings of risk sharing, through consideration of the needs that it has led to the personal needs and ethical behavioral morals.

2. Inspirational Motivation, which is reflected is the behavior of a leader who can make himself an inspiration to his or her employees and always motivate.The character of a leader who has a high standard will but be able to push subordinates to achieve that standard. Characters like this will evokeoptimism and high antitrustism of employees.In other words, transformational leaders always inspire and motivate their employees.

3. Intellectual Stimulation, which can be explained that a leader must characterize who is able to encourage his / her employees to solve the problem carefully and rationally. In addition, these 
characters encourage employees to define new, more effective ways of solving problems. In other words, transformational leaders are able to encourage employees to be creative and innovative.

4. Individualized Consideraion, which is described by a leader who is always listening attentively and paying special attention to the needs and needs of the people he led.

Each and every one of the organizations is a group of people as members of the organization, including the role of the leader. Every day always interacts with another greeting, both in performing work and outside work. The intentions are formal and informal, only to be harmonious in an effective and efficient manner when each member accepts, respects and carries out the same values or norms in the organization. those values and norms are the organizational cultures. Jonathan (2014: 183), organizational culture has been defined in several different ways. Organizational culture can be defined as mutual values and beliefs that enable members to understand their role in organizational and organizational norms. According to Robbins (2006: 721) states organizational culture refers to the common sense system embraced by members who distinguishing the organization from other organizations. In line with Schein (2006: 44) organizational culture is defined as a pattern of basic assumptions created, found, or developed by a particular group when learning to face external adaptation issues and internal integration that has been good enough to be considered valid and therefore, to is taught to new members as the correct way to perceive, think and feel about the problems it faces.Wirawan (2007: 9) defines organizational culture as a set of shared values that control the interactions of each member of the organization, as well as with suppliers, customers and other parties outside the organization.

According to (Robbins 2006: 721) there are 7 important elements in measuring the extent to which the organization's culture has an influence on employee performance.

1. Innovation and risk reinstatement, the level of employee's ability to be innovative and daring to take risks.

2. Attention to detail, the level of demands on employees to be able to pay attention to detail and attention to detail.

3. Orientation on results, the level of management demands to better satisfy the results, rather than the attention of techniques and processes used to achieve results.

4. Orientation of individuals, the level of management's decision in considering the effects of individual dividends in the organization.

5. The orientation of the team, the level of work activity organized in the team rather than individually.

6. Aggressiveness, the level of demands for people to be aggressive and competitive and not relaxed.

7. Stability level of organizational activity emphasizes in defending the status quo as opposed to growth.

Each of the above characteristics is in one unit, from a low level to higher level. Assessing an organization using these seven characteristics creates an overview of the organization's culture. The picture then becomes the basis for the mutual understanding of each member of the organization about their organization.

\section{Methods}

This research is quantitative research, number of sample in research and for research purposes hence amount of sample that will be used as responder for research interest as much as 262 respondent. To obtain the data required in this study, will be done in the following ways Questionnaire:

\section{Test the validity}

The validity test aims to find out the extent of the validity of a data obtained from the questionnaire spread. According to Ghazali (2005: 171), for that item analysis is done using product 
moment correlation pearson (r) method. The validity test with this method is done by correlating the answer scores obtained on each item with the total score of the entire item. In determining the validity or invalidity of a question item by comparing the value of the correlation coefficients or $\llbracket \mathrm{r} \rrbracket$ _count (correlation between question items by total), if the value $\llbracket \mathrm{r} \rrbracket$ _count $>$ critical value means the question item is valid and vice versa when $\llbracket \mathrm{r} \rrbracket$ _count $<$ Critical value means the question item is invalid. Instrument details are valid if pearson correlation / $r$ is critical $>0.30$ (Sugiyono, 2004: 126)

\section{Test Reliability}

Reliability tests aim to measure research instruments based on different perspectives and techniques and to see the stability of a data, which is done by calculating cronbach alpha to test the feasibility of consistency across the scale used. According to Ghazali (2005: 133) if the coefficient of cranbach alpha $>0.60$ then the data can be declared reliable or reliable.

\section{Test the normality}

Is a test used to see the pattern of data dissemination whether or not normally distributed, beside that the normality test can also be used to determine what statistical tests will be used in a study whether using parametric and non parametric tests. The normal or not a data can be seen from the value of asym sig generated in testing $>0.05$. If the normal data is parametric statistical test can be done and vice versa.

\section{Analysis Techniques}

Descriptive Analysis Descriptive analysis aims to describe the characteristics of each of the research variables by presenting the data into frequency distribution tables, calculating the centralization (in terms of mean, median and mode) and disperse values (standard deviation or coefficient of variation) and interpret it.

$$
\text { Average score }=\Sigma(\mathrm{i} \times \mathrm{Fi})
$$

\section{Description:}

i: Weight value of $1,2,3,4,5$

Fi: Frequency response respondents for weight statements

i statements

n: respondents

Respondent's Total respondent is a measure for calculating each category of answers from descriptive variables, then can be calculated by using the formula TCR

Where:

TCR: Respondent's Access Level

Rs: Average scores n: Answer Score Value Respondent's answer criteria, used Sudjana classification (2001) as follows:

$\begin{array}{ll}90 \%-100 \% & \text { Very Good } \\ 80 \%-89 \% & \text { Good } \\ 65 \%-79 \% & \text { Sufficiently Good } \\ 55 \%-64 \% & \text { Not Good } \\ 0 \%-54 \% & \text { Not Good }\end{array}$

\section{Path Analysis}

Path analysis is an analytical technique used to analyze causal interventions that are inherent between variables that are organized on a sequence of temporal with

using coefficient of pathways as a value scale in determining the magnitude of the effect of exogenous independent variables on dependent variables (Sarwono, 2011). To prove the hypothesis that has been expressed then in this case the data has been collected will be processed with the aid of parametric analysis using SPSS (statistical package for social sience). Data analysis model is path analysis 
method. That is to know the extent of the effect of the variable of the cause to the other set of variables which are the variables resulting from both directly and indirectly through the intervening variables that can be seen through the diagram as follows:

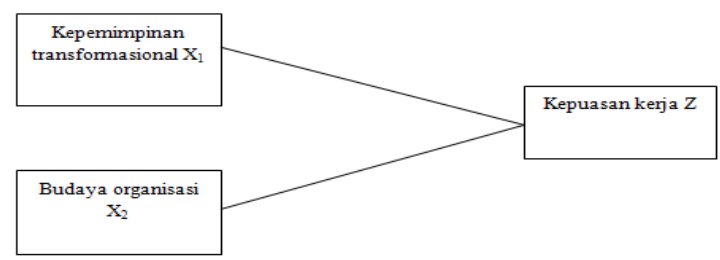

Figure 1 Framework of structure 1

Sub structure I was conducted to analyze the influence of transformational leadership and organizational culture on performance. The results of sub-structure analysis I are shown in the following table:

Table 1 The results of sub-structure analysis 1

\begin{tabular}{|c|c|c|c|c|}
\hline $\begin{array}{l}\text { Variable } \\
\text { Endogen }\end{array}$ & Variable Eksogen & $\begin{array}{c}\text { Path } \\
\text { Koefisien }\end{array}$ & Probability & Description \\
\hline \multirow{2}{*}{$\begin{array}{c}\text { job } \\
\text { satisfactio } \\
n(Y)\end{array}$} & $\begin{array}{l}\text { Transformasional } \\
\text { leadership }\left(X_{1}\right)\end{array}$ & 0,162 & 0,004 & Significant \\
\hline & $\begin{array}{l}\text { Organizational Culture } \\
\left(X_{z}\right)\end{array}$ & 0,476 & 0,000 & Significant \\
\hline
\end{tabular}

Sources : Data Processed

Data analysis on substructure I can be incorporated into the following equation: $\mathrm{Z}=$ Qzx1.X1+ ezx2.X2 + e2Z = 0,161 X1 + 0, 476X3 + e2The large coefficient of the influence of other variables outside the research model to job satisfaction can be calculated using the following formula:"oye2 =" $\sqrt{ }$ ("1-" "r"

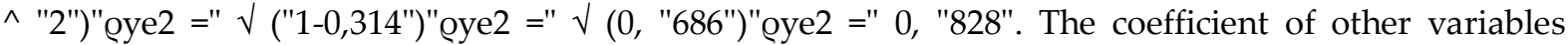
influence work motivation is 0,8282 so it is known that the influence of other variables on work motivation outside the transformational leadership and organizational culture is $68,6 \%$ with calculation $0,828 \times 0,828=0,686$

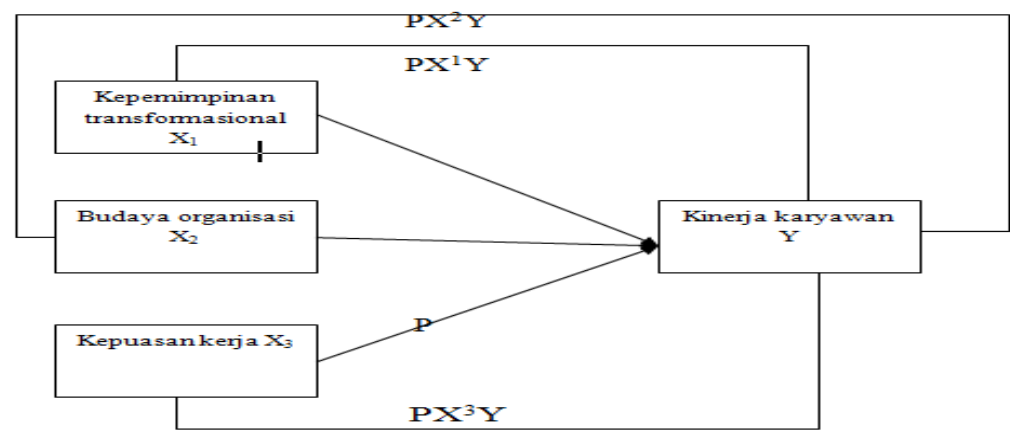

Figure 2 Framework of structure 2

Structure II is done to analyze the influence of transformational leadership, organizational culture and job satisfaction toward employees. The results of sub-structure analysis II are shown in the following table: 
Table 2 The results of sub-structure 2 analysis

\begin{tabular}{|c|c|c|c|c|}
\hline $\begin{array}{l}\text { Endogen } \\
\text { ous } \\
\text { Variables }\end{array}$ & Exogenous Variables & $\begin{array}{c}\text { Path } \\
\text { Koefisien }\end{array}$ & Probability & Description \\
\hline \multirow{3}{*}{$\begin{array}{c}\text { Employe } \\
\text { e } \\
\text { Performa } \\
\text { nce }(Y)\end{array}$} & $\begin{array}{l}\text { Transformasional } \\
\text { leadership }\left(X_{1}\right)\end{array}$ & 0,111 & 0,000 & Significant \\
\hline & $\begin{array}{l}\text { Organizational Culture } \\
\left(\mathrm{X}_{2}\right)\end{array}$ & 0,151 & 0,002 & Significant \\
\hline & job satisfaction $(\mathrm{Z})$ & 0,558 & 0,000 & Significant \\
\hline \multicolumn{5}{|c|}{$R$ Square $=0,493$} \\
\hline
\end{tabular}

Source : Data Processed

The results of data analysis on substructure II can be incorporated into the path equation as follows:

$\mathrm{Y}=$ eyx1.X1 + อyx2.X2 + + @yz.z + e1

$\mathrm{Y}=0,111 \mathrm{X} 1+0,151 \mathrm{X} 2+0,558 \mathrm{Z}+\mathrm{e} 1$

The large coefficient of the influence of other variables outside the research model to employee performance can be calculated using the following formula:

"eye1 =" $\sqrt{ }(" 1-"$ "r" ^ "2")

"oye1 =" $\sqrt{ }(" 1-0,493 ")$

"eye1 =" $\sqrt{ }(0, " 507 ")$

"eye1 =" 0, "712"

The coefficient of other variables influence employee performance is 0,712 so it is known that the influence of other variables on employee performance beyond transformational leadership variables, organizational culture and job satisfaction is $50,7 \%$ with calculation $0,712 \times 0,712=0,507$

\section{Result and Discussion}

The Influence of Transformational Leadership on Employees's Performance in Ibn Sina hospital

Transformational leadership has a significant effect on the performance of RSI Ibn Sina employees in West Sumatra. This means transformational leadership determines employee performance. The coefficient of transformational leadership influence on employee performance is 0.111 and positive value. It means the better of transformational leadership then the performance of employees will increase.

\section{The Influence of Organizational Culture on Employees Performance in Ibn Sina hospital}

This research proves that organizational culture has a significant effect on the performance of $\mathrm{Ibnu}$ Sina Islamic Hospital employees in West Sumatra with a positive value coefficient of 0.151 . This means that there is an increase in organizational culture, it can improve the performance of Ibnu Sina Islamic Hospital employees in West Sumatra. Descriptive analysis results also found aggressive indicators have the lowest achievement achievement of $72.3 \%$ with average score of 3.61 in good category. That means the company has not been able to direct employees to be aggressive and competitive. Employees are still working hard, not in accordance with the procedures in Ibnu Sina Islamic Hospital and the company is perceived to have not paid attention to employees so this affects the achievement of less optimal work. The results of this study in the opinion of Kotter and Heskett (1997) say that strong cultures can produce effects that greatly affect individuals and performance, 
even in a competing environment the influence can be greater than other factors such as organizational structure, financial analysis tools, leadership and others. Organizational culture that is easy to adapt to time change (adaptive) is that can improve performance. In addition, the results of this study are also in line with the results of the study conducted by Pratini (2016) that the organizational culture has influence on performance. So, organizational culture has a positive and significant effect on employee performance.

\section{The Influence of Transformational Leadership on Employee Satisfaction in Ibn Sina hospital}

This study also revealed that transformational leadership has a significant effect on the satisfaction of Ibnu Sina Islamic Hospital employees in West Sumatra. The path coefficient of transformational leadership influenced by 0.162 , meaning that its influence is positive. That is, if transformational leadership goes well, it will be able to increase the job satisfaction of RSI Ibn Sina employees in West Sumatra. The result of this research is in line with Ritawati (2013) findings that the influence between job satisfaction on the performance of transformational leadership employees has a positive and significant influence on job satisfaction. And supported by Hartanto (2012), the transactional leadership style variables have a significant influence on job satisfaction.

\section{The Influence of Organizational Culture on Employee's Satisfaction in Ibnu Sina hospital}

Research findings indicate that organizational culture has significant effect on job satisfaction of Ibnu Sina Islamic Hospital employees in West Sumatra. Based on the band analysis, the regression coefficient is positive value of 0.476 with a significance level of $0,000<0.005$. So the hypothesis that has been formulated according to the result of the research so that the fourth hypothesis can be accepted that organizational culture has a positive and significant effect on the satisfaction of Ibnu Sina Islamic Hospital employees in West Sumatra. The results of the research in line with the research conducted by Riwati (2013) proved that organizational culture has positive and significant influence to job satisfaction. This is in line with the CFA results, that employee-owned organizational culture is able to give an impression and individual message within the individual employee who has understood the organizational culture to be able to provide individual satisfaction for the work, and to produce that organizational culture has a significant effect on job satisfaction.

\section{The influence of Job Satisfaction on Employee's Performance in hospital Ibn Sina Hospital}

The hypothesis test shows that job satisfaction has a significant effect on the performance of Ibnu Sina Islamic Hospital employees in West Sumatra. Based on path analysis, the regression coefficient is 0.558 with the significance level of $0,000<0.05$. This result is concluded that the research hypothesis is accepted that organizational culture has a positive and significant effect on the performance of Ibnu Sina Islamic Hospital employees in West Sumatra. from the result of descriptive test the job satisfaction variable has the total achievement of respondents only $73 \%$ with average 3,65 is in good enough category, so it is necessary to increase work satisfaction that can improve employee performance. By knowing the satisfaction of work performance decreased, Ibnu Sina Islamic Hospital in West Sumatra has not been able to increase employee satisfaction. From the result of descriptive analysis found that the working condition indicator has the lowest Respondent Total Respondent value which is $72 \%$ with average 3,60 score is in good enough category. The results of this study are in line with Brahmasari (2008) research, proving that employee job satisfaction has a positive and significant effect on the company's performance, meaning that in general, high employee satisfaction will be able to improve the company's performance. 


\section{The Influence of Transformational Leadership on Employee's Performance with Job Satisfaction as an Intervening Variable in Ibn Sina hospital}

Transformational leadership has an effect on employee performance through job satisfaction as a mediator in Ibnu Sina Islamic Hospital West Sumatra. In this research it was found to be $1 \%$ of its influence Previously found that directly transformational leadership has an influence on employee performance. Transformational leadership has an influence on employee performance. So in relation between transformational leadership and employee performance there is job satisfaction as mediation variable. Improved transformational leadership can increase job satisfaction so that employee performance is increasing. The results of this study in line with Kurniawan's research, et al (2013) states that transformational leadership has an indirect influence on employee performance through job satisfaction. The results of Kovjanic research, et al (2013) state that there is a transformational leadership influence on employee performance mediated by job satisfaction. That is, when transformational leadership can be well understood by members, it will have an impact on the improvement of job satisfaction.

\section{The Influence of Organizational Culture on Employee's Performance with Job Satisfaction as the Intervening variable in Ibn Sina hospital}

Organizational culture has a significant effect on employee performance through job satisfaction as an intervening variable in Ibnu Sina Islamic Hospital in West Sumatra in this research was found at $4 \%$. Previously found that the organizational culture directly affected the performance of employees. So in relation between organizational culture and employee performance there is job satisfaction as intervening variable. Increasing organizational culture can increase job satisfaction so that employee performance is increasing. The result of this research is in line with Mustika and Utomo (2013) research that organizational culture indirectly gives a significant influence to employee performance improvement through job satisfaction variable. Sustainable Research and Suryani (2018) found that job satisfaction was able to mediate partially the organizational culture relationship to employee performance.

\section{Conclusion}

1. Transformational leadership has a positive and significant impact on employee performance. This means that good transformational leadership can directly affect the performance of employees in working. The better the trasformational leadership then the performance of employees will increase.

2. Organizational culture positively and significantly influence the performance of employees. This means that there is an increase in organizational culture, it can improve the performance of Ibnu Sina Islamic Hospital employees in West Sumatera.

3. Transformational leadership also has a significant influence on the job satisfaction of Ibnu Sina Islamic Hospital employees in West Sumatera. The correlation coefficient of transformational leadership influence on work satisfaction is positive value is 0,162 . This means that if transformational leadership works well, it will be able to improve the job satisfaction of Ibnu Sina Islamic Hospital employees in West Sumatera.

4. Organizational culture gives a significant and positive influence on job satisfaction of Ibnu Sina Islamic Hospital in West Sumatera with a path coefficient of 0.476. This indicates that a strong and good organizational culture will tend to increase the satisfaction of Ibnu Sina Islamic Hospital employees in West Sumatera.

5. Job satisfaction has a significant and positive influence on employee performance with path coefficients of 0,558 . This means that the performance of the employees depends on the satisfaction of the work they perceive. Employee performance will increase in line with increased job satisfaction and vice versa.

6. The influence of transformational leadership on employee performance through job satisfaction as an intervening variable is $1 \%$. So in the relationship between transformational leadership and 
employee performance there is job satisfaction as an intervening variable. This means transformational leadership applied by employers can increase employee satisfaction that impacts on employee performance.

7. The influence of organizational culture on employee performance through job satisfaction as an intervening variable is $4 \%$. So in relation between organizational culture and employee performance there is job satisfaction as intervening variable. This means that the improvement of organizational culture can increase employee satisfaction so that employee performance is increasing

\section{Reference}

Ardiansyah, Dimas Okta. (2016). Pengaruh Komunikasi Terhadap Kinerja Karyawan Dengan Mediasi Kepusan Kerja. Journal Universitas Brawijaya: Malang. Volume: 3 Hal: 16 - 30.

As'ad, M. (2003). Psikologi Islam: Seri Manajemen Sumber Daya Manusia. Yogyakarta: liberty.

Aw, Suranto.(2010). Komunikasi Sosial Budaya. Yogyakarta :Graha Ilmu

Depari, Edwar.(1999). Teori Komunikasi Massa: Suatu Pengantar. Jakarta: Erlangga.

Ferdinand, agusty.(2002).Analisis Structural Equation Model (SEM): Analysis of Moment Structures (AMOS). Universitas Diponegoro : Badan Penerbit Universitas Diponegoro.

Ferdinand, Agusty.(2014). Metode Penelitian Manajemen. Edisi 5. Universitas Diponegoro : Badan Penerbit Universitas Diponegoro.

Dessler, Gery.(2015). Manajemen Sumber Daya Manusia. Edisi 14. Jakarta : Selamba Empat

Gibson, Ivancevich, Donnely.(1997). Organizations (Terjemahan). Cetakan Keempat. PT. Gelora Aksara Pratama:Jakarta.

Gibson, James L. John M.I, James H. Donely, (1997) : Organisasi, Perilaku, Struktur, Proses :Jakarta: Inter Aksara.

Gibson et al. (2012). Organization. Behavior structure processes. Eight edition: Boston: Richard D Irwin Inc Homewood.

Gitusudarmo, Indriyo \& Sudita, I Nyoman.(2008). Prilaku Keorganisasian. Edisi pertama. Yogyakarta: BPFE

Giyarni, Suseno \& Triastity. (2016). Pengaruh Gaya Kepemimpinan, Motivasi Kerja Dan Komunikasi Terhadap Kinerja. Journal Universitas Slamet Riyadi: Surakarta Volume: 10 Hal: 199-132.

Handoko, Hani, T. (2000). Manajemen Sumber DayaManusia. Edisi Keempat. BPFE UGM:Yogyakarta.

Handoko, Hani, T.(2001). Manajemen. Yogyakarta: BPFE.

Hasibuan, Melayu.(2008). Manajemen Sumber Daya Manusia.Jakarta: PT. Bumi Aksara.

Hasibuan, Melayu .(2012). Manajemen Sumber Daya Manusia.Jakarta: PT. Bumi Aksara.

Hughes, Ginneft \& Curphy. (2012). Leadership: memperkaya pelajaran dan pengalaman. Jakarta: Selemba Humanika.

Ida Ayu bramahasari dan Agus Suprayetno. (2008). Pengaruh bmotivasi kerja, kepemimpinan dan Budaya organisasi terhadap kepuasan dan Kinerja Perusahaan PT. pei hai internasional wiratama Indonesia. Tesis Universitas 17 Agustus : Surabaya. Volume: 10 Hal: 124 - 135

Istijanto. (2010). Riset Sumber Daya Manusia. Jakarta: PT. Gramedia Pustaka Utama.

Ivancevich, John M. Robert Konopaske, Michael T. Matteson. (2006). Perilaku dan Manajemen Organisasi. Edisi Ketujuh. Jilid 1. Jakarta : Erlangga.

Ivancevich, Jonh.dkk.(2005). Perilaku dan Manajemen Organisasi. Edisi ketujuh. Jakarta: Erlangga.

Jatilaksono, Raditia Siggih. 2016. Pengaruh Disiplin Kerja Dan Budaya Organisasi Terhadap Kinerja Karyawan CV. Abank Irenk Creative. Journal Universitas Negri Yogyakarta. Volume: 7 Hal: 588 603

Karabay, dan Efe. (2012). The Effects Of Leadership Styles The Communication Compentency Of Bank Managers On The Employees Job Satisfaction: The Case Of Turkish Banks. Marma and Baykent University: Istanbul Volume: 58 Hal: 227 - 235

Kartini Kartono. (2006). Human Behaviour at Work Organijational Behaviour 9 th Education. Newyork Mc.Grew bil Graw Hil, Inc 
Koesmono H. Teman. (2005). Pengaruh Budaya Organisasi terhadap Motivasi dan Kepuasan Kerja serta Kinerja Karyawan pada Sub Sektor Industri Pengolahan Kayu Ekspor di Jawa Timur. Disertasi Universitas Airlangga: Surabaya.

Luthans, Fred.(2006). Prilaku Organisasi, (ahli bahasa V.A yuwono, dkk). Edisi bahasa Indonesia. Yogyakarta: andi.

Lutan, Fred \& P.Doh, Jonathan. (2014). Manajemen Internasional: Budaya, Strategi, Dan Prilaku. Edisi 8. Jakrta : Salemba Empat.

Mangkunegara Anwar Prabu. (2005). Manajemen Sumber Daya Manusia Perusahaan. Cetakan Keenam. PT. Remaja Rosdakarya: Bandung.

Mangkunegara Anwar Prabu. (2005). Perilaku dan Budaya Organisasi. Cetakan Pertama, PT. Refika Aditama, Bandung.

Muhammad, Arni. (2014). Komunikasi Organisasi. Jakarta : Bumi Aksara

Ngadiman.(2013).Pengaruh Kepemimpinan,Rekrutmen Dan Kompensasi Terhadap Kinerja Karyawan Perusahaan PT Selat Di Jakarta.

Nugraheny, Penny Setyawati. (2009). Analisa Pengaruh Kepuasan Kerja, Dukungan Organisasi, dan Gaya Kepemimpinan Terhadap Motivasi Kerja Dalam Meningkatkan Kinerja Karyawan PT. Bank Mandiri kota Semarang. Thesis. Universitas Diponegoro: Semarang.

Purwanto, Djoko.(2007). Komunikasi Bisnis. Jakarta: Erlangga.

Raharjo, Susilo Tito.(2006). Analisa Pengaruh Kepemimpinan Terhadap Kepuasan Kerja, Komitmen Organisasi Dan Kinerja Karyawan. Journal Universitas Diponegoro: Semarang. Volume: 3 Hal: 69 81

Rivai, Veitzal.( 2003). Manajemen Sumber Daya Manusia Untuk Perusahaan. Jakarta: Grafindo

Rivai, Veithzal. (2004). Manajemen Sumber Daya Manusia untuk Perusahaan Murai Kencana. Jakarta.

Rivai, Veitzal. (2009). Manajemen Sumber Daya Manusia Untuk Perusahaan: Dari Teorike Praktek. Jakarta: Raja Wali Press.

Robbins, Stephen P \& Judge, Timothy A. (2008). Organizational Behavior. Edisi 12. Prentice Hall, Inc., New Jersey.

Robbins, Stephen P. (2006). Perilaku Organisasi, Edisi Sepuluh. Jakarta : Indeks Kelompok Gramedia.

Robbins, Stephen P. (2009). Evaluasi Kinerja Sumber Daya Manusia : Teori, Aplikasi dan Penelitian. Jakarta : Salemba Empat.

Ritawati, Agustina.(2013). Pengaruh Kepemimpinan Transformasioanal dan Budaya Organisasi Terhadap Kepuasan Kerja dan Kinerja PT. Jamsostek cabang Surabaya. Journal Universitas 17 Agustus: Surabaya. Volume: 9 Hal: 82 - 93

Rudianti, Yulistian A. (2011). Hubungan Komunikasi Organisasi Dengan Kinerja Perawat Rumah Sakit Swasta Surabaya. Thesis. Universitas Indonesia: Bogor

Sehfudin, Arif. (2011). Pengaruh gaya kepemimpina. Komunikasi organisasi dan motivasi kerja terhadap kinerja karyawan PT. Bank BTPN cabang Semarang. Journal Universitas Diponegoro: Semarang.

Sekaran, Uma. (2006). Metodologi Penelitian Untuk Bisnis. Edisi keempat. Jakarta: Salemba Empat.

Siagian, Malayu. (2003). Manajemen Sumber Daya Manusia. Bumi Aksara: Jakarta.

Sugiyono. (2004). Metode Penelitian Administrasi (Edisi Kelima). Bandung: Alfabeta.

Sutiadi john. (2003). penilain kinerja dan pengembangn karyawan. Cetakan Kelima Bagian Penerbitan Fakultas Ekonomi Univrsitas Gajah Mada. Yogyakarta.

Satiawati \& Suwartana.(2014). Pengaruh Gaya Kepemimpina Dan Budaya Organisasi Terhadap Kepuasan Kerja Serta Dampak Terhadap Kinerja Karyawan Lembaga Perkreditan. Journal Universitas Udayana: Bali. Volume: 6 Hal: 17 - 32

Sutrisno, Edy.(2010). Budaya Organisasi. Edisi Pertama Cetakan Ke-1. Jakarta : Kencana.

Sylvana Andi.(2002). Pengaruh Gaya Kepemimpinan terhadap Kinerja dan Kepuasan Kerja Anggota Polri Polda Metro Jaya. Jurnal Universitas Terbuka: Jakarta.

Thoha, Miftah.(2010). Kepemimipinan Dalam Manajemen. Jakarta: Raja Grapindo Persada. 
Thoyib Armanu.(2001). Pengaruh Faktor Motivasi Terhadap Prestasi Kerja Karyawan Pada Kantor Perum Perhutani Unit Ii Surabaya. Jurnal Fakultas Ekonomi Universitas Brawijaya: Malang.

Tri, Utami \& Ruhana.(2016). Pengaruh Komunikasi Organisasi Terhadap Knowlage Shering Dan Kinerja Karyawan Hotel Gajah Mada Graham Malang. Journal Universitas Brawijaya: Malang. Volume: 35 Hal: 86 - 93

Usman, Husein.(2010). manajemen: Teori, Praktek, Dan Riset Penelitian. Jakarta: PT. Gramedia pustaka utama.

Wibowo. (2006). Manajemen Perubahan. Cetakan Pertama. PT. Rajagrafindo Persada: Jakarta.

Wibowo. (2011). Manajemen Kinerja. Edisi Ketiga. Jakarta: PT. Raja Grafindo Persada.

Wiraw. (2007). Budaya dan Iklim Organisasi : Teori Aplikasi dan Penelitian. Jakarta : Salemba Empat.

Wirawan. (2015). Manajeman Sumber Daya Manusia: Teori, Psikologi, Hukum Ketenagakerjaan, Aplikasi, Dan Penelitian: Aplikasi Dalam Organisasi Bisnis, Pemerintah Dan Pendidikan. Cetakan Pertama. Jakarta: Rajawali Pers

Zimeres. (2015). Relation Between Job Satisfaction And Job Performance In The Healthcare Service. University Of The Aegean : Greece. Volume: 175 Hal: 480 - 487 